nejbližší okolí nebyl jeho zhoršující se zdravotní stav tajemstvím, všechny, kteří pana profesora znali osobně, tato smutná zpráva bolestně zasáhla. $Z$ četných neformálních projevů soustrasti, které různými cestami přicházely na jeho mateřské pracoviště, bylo zřejmé, že mnozí vnímají tento smutný fakt jako skutečnou osobní ztrátu. Jako uvědomění si zraňující skutečnosti, že přišli o další možná dosud plně neuvědomovaný, ale pro pocit sounáležitosti se světem lidí nesmírně důležitý pocit vnitřní spř́ízněnosti s dobrým, laskavým, chápajícím a soucitným člověkem. Lidský profil osobnosti Stanislava Žaži představoval všechno to, čeho se nám nejen $\mathrm{v}$ akademickém prostředí stále více nedostává: nesobeckost, obětavost, kolegiálnost, přátelskost, skromnost, pokoru, lidskost.

Vážený a milý pane profesore, budeme na Vás vždy s úctou, láskou a vděčností vzpomínat.

fiři Gazda

https://doi.org/10.5817/OS2018-4-5

\title{
Vzpomínka ryze osobní
}

Nevím, zda je vhodné publikovat $\mathrm{v}$ odborném časopise žánr vzpomínky, proto nechám zcela na redakci, zda tento prríspěvek otiskne. Navíc má tento žánr jedno úskalí: nevyhne se tomu, aby kromě toho nebo těch, na něž se vzpomíná, nezahrnul i vzpomínajícího, takže pak se může stát, že čtenář má dojem určité nepatřičnosti. I s tímto vědomím však píšu následující ráádky.

Rok 2018 zůstane v dějinách naší rusistiky rokem, kdy ji navždy opustili její dva přední představitelé, pan profesor Stanislav Žaža a pan docent Václav Huňáček. Jejich odborný př́nos oboru bude určitě zhodnocen někým povolanějším. Já za sebe na ně chci vzpomenout jako na své nikoli učitele - věkový rozdíl mezi námi nebyl tak velký ale vážené kolegy, kterým jsem se ze srdce obdivovala, kteří byli mým vzorem, kteří po smutném odchodu mého pana profesora Vladimíra Barneta mi ze staré generace „zůstali“ na dvou rusistických katedrách, ke kterým jsem měla nejblíž i duchovně, i vzdáleností (protože jsem sice 41 let působila na UJEP v Ústí nad Labem, ale celý život jsem žila v Havličkově Brodě, ležícím na spojnici mezi Prahou a Brnem - pro spravedlnost musím však ještě dodat, že jsem duchovně měla blízko i k dalšímu významnému rusistickému pracovišti na FF UP v Olomouci.)

Prof. PhDr. Stanislav Žaža, CSc. se narodil 14. dubna 1929 a zemřel 5. srpna 2018 ve věku 89 let. Jeho oborem byla latina-ruština, profiloval se jako lingvista par excellence. Působil na Masarykově univerzitě v Brně. Já jsem ho znala z jeho publikační činnosti, ale především $\mathrm{z}$ různých konferencí a hlavně jako oponenta desítek rigorózních 
a habilitačních prací. Mnohokrát jsme se sešli „nad jednou prací “ $v$ této roli, nikdy se nestalo, že by se naše posudky zásadně lišily, ale vždy jsem obdivovala, když se mi jeho posudek před obhajobou dostal do ruky, jaké nuance, jaké souvislosti v práci našel, vždy jsem se i já z jeho posudku poučila. Nebylo náročnějšího, ale také laskavějšího oponenta - a vůbec laskavějšího člověka. Na různých odborných kongresech a zasedáních byl často „spravedlivým“ předsedajícím, ale i pouze jako účastník nikdy nechtěl dopustit, aby zajímavá myšlenka zapadla, vystoupil v diskusi, udal směr dalšího rokování. - A i když nevím, jestli je to vhodné, chci připomenout ještě př́hodu z jedné obhajoby. Stalo se už po roce 1989, pan profesor omylem oslovil prŕtomné „Vážení soudruzi“ (hned si to ovšem uvědomil). V zasedací místnosti to zašumělo, ale vždyṫ tití̌ lidé sami ještě před nedávnem tohoto oslovení užívali. A jestli slovo „soudruh“ předtím, než bylo politicky zneužito a jeho obsah „vyprázdněn“, mělo původní smysl, do něhož patřila soudržnost, prátelství, ochota k podání ruky a pomoci, pak všechny tyto vlastnosti v míře vrchovaté představoval právě pan profesor Žaža. Čest jeho památce, kéž je v oboru více lidí jeho ražení.

Doc. PhDr. Václav Huňáček, CSc. se narodil 15. ledna 1931, zemřel 7. srpna 2018 ve věku 87 let.

Vystudoval angličtinu-ruštinu, proslul jako znalec ruské a slovanské historie $\mathrm{v}$ jejích evropských a světových souvislostech. Především ho zajímaly kulturní a náboženské dějiny v návaznosti na dějiny jazyka, měl kontakty se světovými badateli v těchto oborech. Působil na FF UK v Praze. Znala jsem ho nejdřív prostřednictvím pana prof. Barneta jako nepřehlédnutelného člena pražské katedry rusistiky, k němuž její členové chovali obdiv a úctu, i když si někdy spíše z legrace stěžovali na jeho určitou „svéráznost“. Byl proslulý svými exkurzemi, které pořádal pro studenty i zahraniční slavisty po Praze a okolí, ale také do zahraničí, namátkou uvedu německé Řezno, francouzskou Remeš, madarský Visegrád. I když jsem do těchto skupin vlastně nepatřila, po léta jsem se jeho pražských exkurzí účastnila a vždy žasla nad spoustou souvislostí, které si člověk neuvědomuje. Snad je i vinou školské výuky, že se učíme dějiny jakoby izolovaně, pro každou zemi zvlášt, bez znalostí spojitostí, i když právě ony „hýbou světem“. To vše bylo ve výkladu doc. Huňáčka zcela běžné. Kdo by se o tom chtěl dnes přesvědčit bez složitého hledání, doporučuji jeho kapitolu ve vynikající publikaci Sázava, Památník staroslověnské kultury v Čechách, Odeon 1988, nazvanou Sázava v širších vztazích a souvislostech. V ní je vidět způsob svébytného uchopení tématu, který byl doc. Huňáčkovi vlastní. - A jestli mohu i u něho vzpomenout na jednu příhodu, tak tedy: když na jedné z exkurzí vykládal doc. Huňáček o prvním českém králi Vratislavovi, zmínil, že utýral svou manželku. Já brzy nato jela na nějakou konferenci do Olomouce, ve volném čase jsem tam navštívila muzeum a víceméně náhodně jsem si tam o Vratislavovi přečetla, že musel před nepřáteli prchnout do Uher a zanechal v Olomouci svou těhotnou manželku, kterou tam jeho nepřátelé 
utýrali. A tak jsem panu docentovi poslala pohled s textem: „Pozdrav z míst, kde Váš Vratislav zanechal svou manželku prchaje do Uher, viz Kosmova kronika, první zmínka o Olomouci“. A když jsme se pak po čase v Praze sešli, docent Huňáček mi před polovinou katedry děkoval a měl o mně od té doby velmi vysoké mínění (ale zbytečně, to všechno byla náhoda, že jsem si na panelu v muzeu přečetla úryvek z Kosmovy kroniky; nesahala jsem $\mathrm{v}$ historických souvislostech panu docentovi ani po kotníky). Hezky se vzpomíná.

Přála bych si, aby dnešní mladá rusistická generace měla mezi svými učiteli takové vědce a vzory, kterými pro mou generaci byli oba výše jmenovaní. Jestli existuje nějaké rusistické nebe, kéž v něm najdou klid pro svou další práci, protože bez práce si nedovedli život představit. A zde na zemi at je jejich odborné dílo pořád vyhledáváno a inspiruje mladé badatele. A mezi námi, kteří jsme je znali osobně, at zůstane vzpomínka na ně vždycky živá.

Zdeňka Trösterová 